\title{
Crape Myrtle Post-transplant Growth as Affected by Nitrogen Nutrition during Nursery Production
}

\author{
Raul I. Cabrera ${ }^{1}$ and Diana R. Devereaux ${ }^{2}$ \\ Department of Plant Science, Rutgers University, 59 Dudley Road, New Brunswick, NJ 08901
}

\begin{abstract}
ADDITIONAL INDEX wORDs. landscape, leaf nutrient concentration, flowering response, nutritional status, shoot to root ratio, transplant

Abstract. Containerized crape myrtle (Lagerstroemia indica L. x Lagerstroemia fauriei Koehne 'Tonto') plants were grown for 9 months under various nitrogen fertility regimes, and then transplanted to a sandy loam soil with minimal management to evaluate their landscape establishment and growth performance. During the nursery phase plants were irrigated, except over an overwintering period, with complete nutrient solutions differing in applied $\mathrm{N}$ concentration, ranging from 15 to $300 \mathrm{mg} \cdot \mathrm{L}^{-1}$. By 16 weeks after transplanting (WAT) into the landscape soil, plant biomass was significantly higher in the plants that had been grown with higher $\mathrm{N}$ supplies and had been among the smallest at transplant. Such plant growth response was linearly and positively correlated to plant $\mathrm{N}$ status at transplant. Plant shoot to root ratio and tissue $\mathrm{N}, \mathrm{Ca}, \mathrm{S}$, and $\mathrm{Fe}$ concentrations, which had been significantly affected by the $\mathrm{N}$ fertilization regime in the nursery, equalized over time after transplant, with no significant differences observed among treatments by 16 WAT. Flowering response in the landscape was delayed in plants originally grown with the higher $\mathbf{N}$ supplies. Plant survival and establishment per se were not affected by treatments; no plants were lost, and aside from the differences in size and flower timing, all plants were considered aesthetically similar.
\end{abstract}

Most woody ornamentals are faced with two distinct growing environments: the nursery and the landscape. Intensive management conditions in the nursery are primarily geared to promote vigorous growth (Wright and Niemiera, 1987), whereas less than optimal conditions await these plants in the landscape (Harris, 1992; Whitcomb, 1986). Most natural environments, including urban landscape settings, are continuously suboptimal with respect to one or more environmental parameters, such as water or nutrient availability (Chapin, 1991). Thus, transplant from a nursery into a landscape setting creates a stressful transition period, critical to the survival and establishment of these plants (Whitcomb, 1986). Substantial research has been devoted to this area of transplant and establishment in the landscape including aspects of production method, root and shoot pruning practices, water relations, mulching, time of planting, planting hole characteristics and backfill composition and type (see Harris, 1992, and Whitcomb, 1986, and references therein). The impact of fertility practices and plant nutritional status at the nursery on plant growth and establishment in the landscape has, however, received limited attention.

Hydroponically grown birch seedlings are able to adapt their shoot and root growth, after a lag phase, to abrupt changes in $\mathrm{N}$ supply (Ingestad, 1979; Ingestad and Lund, 1979). Furthermore, the apparent $\mathrm{N}$ deficiency symptoms developed after the sudden change in $\mathrm{N}$ supply disappeared over time and the plants maintained a healthy leaf color and appearance across a range of tissue $\mathrm{N}$ concentrations. Interestingly, the methodology employed in these experiments emulated the nursery-landscape transition experienced by a woody ornamental, namely the abrupt change from the intensively managed $\mathrm{N}$ fertilization in the nursery (Wright and Niemiera, 1987) and the low $\mathrm{N}$ fertility conditions commonly found in landscape soils (Harris, 1992). Furthermore, these results

Received for publication 11 May 1998. Accepted for publication 6 Oct. 1998 Research funded by the New Jersey Agricultural Experiment Station and the Horticultural Research Institute (Washington, D.C.). We thank Centerton Nurseries for providing plant material. The technical assistance of Linda Santos and Pedro Perdomo is gratefully acknowledged. The cost of publishing this paper was defrayed in part by the payment of page charges. Under postal regulations, this paper therefore must be hereby marked advertisement solely to indicate this fact. ${ }^{1}$ Extension specialist; e-mail: cabrera@ aesop.rutgers.edu.

${ }^{2}$ Former graduate research assistant. suggest that significant changes and adjustments in growth and plant $\mathrm{N}$ status of woody ornamentals may be occurring during the transition phase between the nursery and the landscape.

The present study was conducted to evaluate the relationship between $\mathrm{N}$ fertility management during nursery production and plant growth and performance after transplant to a landscape site with minimum management.

\section{Materials and Methods}

A detailed description of the experimental nursery phase is reported elsewhere (Cabrera and Devereaux, 1998). Briefly, on 8 Aug. 1994, rooted cuttings of crape myrtle (Lagerstroemia indica L. $x$ Lagerstroemia fauriei Koehne 'Tonto') were transplanted to no. $1(3.8-\mathrm{L})$ plastic containers filled with a 2 peat : 1 vermiculite : 1 sand medium (by volume). With the exception of an overwintering period (15 Nov. 1994 to 22 Mar. 1995), plants (12 per treatment) were irrigated with complete nutrient solutions, but varying in applied $\mathrm{N}$ concentration $\left(\mathrm{N}_{\mathrm{A}}\right): 15,30,60,120,210$, and $300 \mathrm{mg} \cdot \mathrm{L}^{-1}$. Nutrient solution was applied two to three times per week during the growing season.

The nursery growing phase ended on 16 May 1995 and four plants from each treatment were randomly selected for harvest. Plant height, canopy diameters (mean of two horizontal measurements perpendicular to each other), and leaf greenness (i.e., chlorophyll) readings were measured with a chlorophyll meter (SPAD-502; Minolta Camera Co., Ltd., Osaka, Japan) before harvest. Plants were then divided into leaves, stems, and roots, and total leaf area was determined with a leaf area meter (LI-3100; LICOR, Lincoln, Neb.). After these measurements, tissues were oven-dried at $70{ }^{\circ} \mathrm{C}$ for at least $96 \mathrm{~h}$, then ground to pass a 40 -mesh screen. Leaf total $\mathrm{N}$ was determined by a modified Kjeldahl digestion procedure coupled with $\mathrm{N}$ analysis by a diffusionconductivity method (Carlson et al., 1990). Phosphorous, K, Ca, $\mathrm{Mg}, \mathrm{B}, \mathrm{Mn}, \mathrm{Fe}, \mathrm{Zn}, \mathrm{Cu}$ and Mo were determined by ICP emission spectroscopy (Scotts Testing Laboratory, Allentown, Pa.) and total sulfur by infrared spectrometry (Agricultural Analytical Laboratory, Pennsylvania State University, College Park, Pa.).

The remaining eight plants from each $\mathrm{N}$ treatment were transplanted, in a randomized complete block design, in a recently 

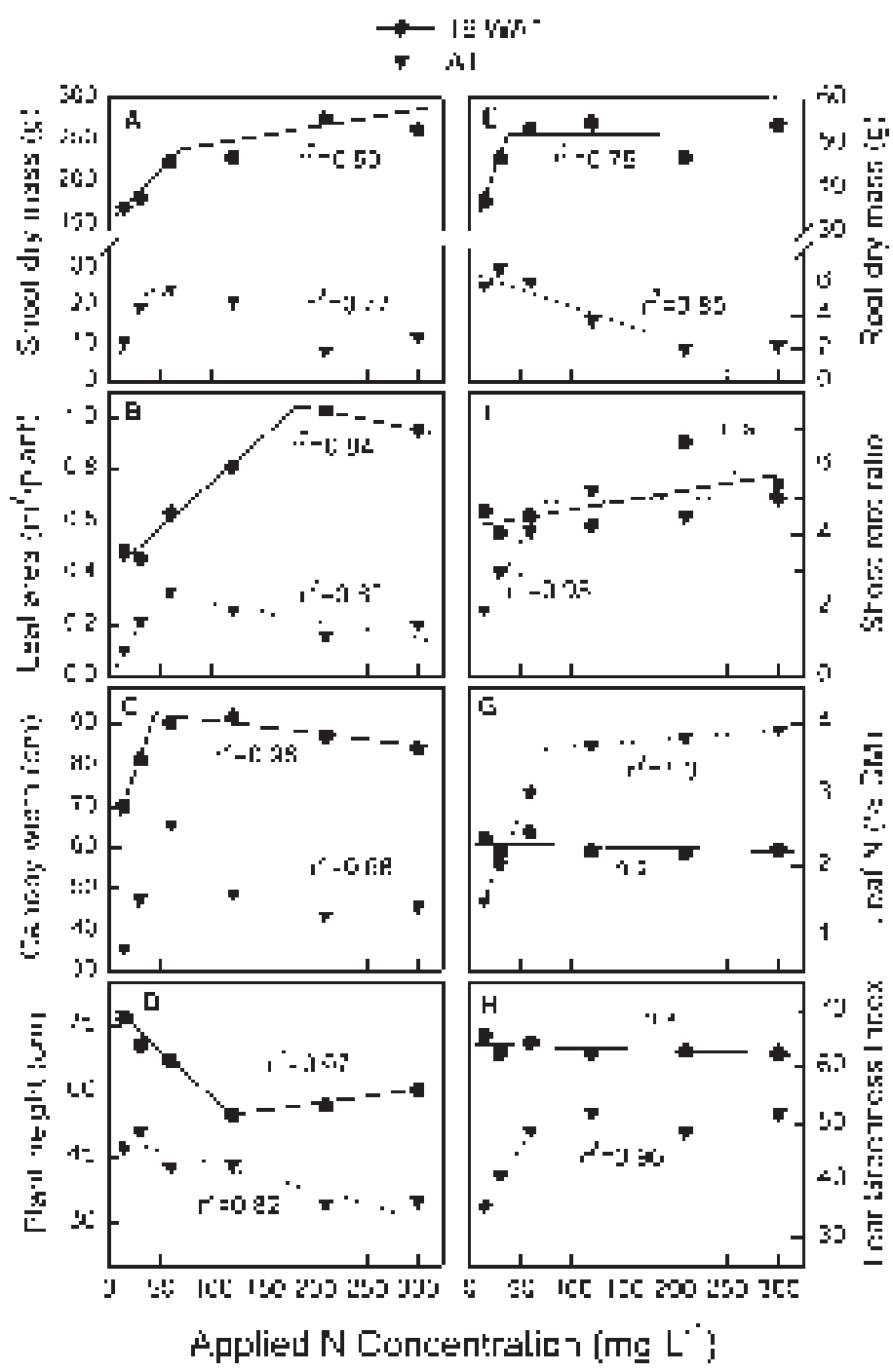

Fig. 1. Effect of $\mathrm{N}$ application rate during nursery production of crape myrtle on plant growth responses at transplant (AT) and 16 weeks after transplanting (WAT) to a landscape soil with minimum management. Data for AT plants is taken from Cabrera and Devereaux (1998). The $r^{2}$ values were calculated as $1-$ $\left[\sum\left(\mathrm{SS}_{\text {errors }}\right) / \mathrm{SS}_{\text {corrected total }}\right]$; remaining statistical parameters are presented in Table 1. Each data point is average of four replications.

prepared Sassafras sandy loam soil (fine-loamy, siliceous, mesic Typic Hapludults) that had been left fallow for 1 year. The soil had a $\mathrm{pH}$ of 5.8, with a background exchangeable $\mathrm{N}$ (ammonium plus nitrate) concentration of $2.6 \mathrm{mg} \cdot \mathrm{L}^{-1}$. Planting holes $(40 \mathrm{~cm}$ in diameter and $18 \mathrm{~cm}$ deep) were spaced in a $1.8 \times 1.8 \mathrm{~m}$ grid to prevent any above- and below-ground competition between plants. No fertilizer or organic amendments were applied to the backfill soil or the planting hole at time of transplant, nor used throughout this phase of the study. The plants were thoroughly watered at transplant and at 1 - to 3 -d intervals (five applications, with $\approx 2 \mathrm{~L}$ per plant per application) during the first 2 weeks to prevent water stress. After this establishment period the plants were nonirrigated, but received a total of $210 \mathrm{~mm}$ of rainfall during the experimental period. Two supplemental overhead sprinkler irrigations $(7.6 \mathrm{~mm}$ each) were, however, needed during a dry period in August. Weeds were controlled both culturally (mechanical and hand weed control) and chemically (Pendimethalin and Isoxaben herbicides according to label recommendations).

Four randomly selected blocks (total of four plants per treat- ment) were harvested on 19 June 1995 [4 weeks after transplant (WAT)] and on 5 Sept. 1995 (16 WAT). Each plant was hand-dug with an average rootball of $60-\mathrm{cm}$-diameter by $30-\mathrm{cm}$-deep, and rootballs were carefully washed free of soil. Harvested plants were then handled and processed after the procedures used at the end of the nursery phase [i.e., at transplant (AT)]. Plant growth during the landscape evaluation phase was calculated as total plant biomass 16 WAT minus total plant biomass AT.

Statistical analyses were performed using SAS v. 6.11 (SAS Institute, Cary, N.C.). Regression and segmented-linear analyses, the latter according to Argo and Biernbaum (1996), were used to evaluate plant growth and nutrient status response variables to applied $\mathrm{N}$ concentration.

\section{Results and Discussion}

Plant growth responses to $\mathrm{N}$ supply during production in the nursery are reported elsewhere (Cabrera and Devereaux, 1998). Briefly, plant shoot biomass and leaf area increased with $\mathrm{N}_{\mathrm{A}}$ up to $60 \mathrm{mg} \cdot \mathrm{L}^{-1}$, but were depressed at higher concentrations, and plant height and root dry mass were linearly depressed with increases in $\mathrm{N}_{\mathrm{A}}$. Four weeks after transplant, plant growth responses remained similar to those recorded AT (data not shown), likely influenced by a residual nursery fertilizer effect. By 16 WAT, however, plants that had been grown with higher $\mathrm{N}$ supplies in the nursery (120 to $300 \mathrm{mg} \cdot \mathrm{L}^{-1}$ ), some of which had been among the smallest in mass and size at transplant, showed significant responses for most measured growth parameters (Fig. 1). Shoot biomass and leaf area from plants originally grown at 210 to $300 \mathrm{mg} \cdot \mathrm{L}^{-1} \mathrm{~N}$ were higher compared to those plants grown at 15 to $60 \mathrm{mg} \cdot \mathrm{L}^{-1}$ (Fig. $1 \mathrm{~A}$ and $\mathrm{B}$ ). Plant canopy diameter response $16 \mathrm{WAT}$, however, remained similar to that observed AT (Fig. 1C). On the other hand, the linear negative response of plant height and root biomass to $\mathrm{N}_{\mathrm{A}}$ observed AT was modified during the 16-week post-transplant evaluation (Fig. 1D and E). Here it is noteworthy to observe the recovery

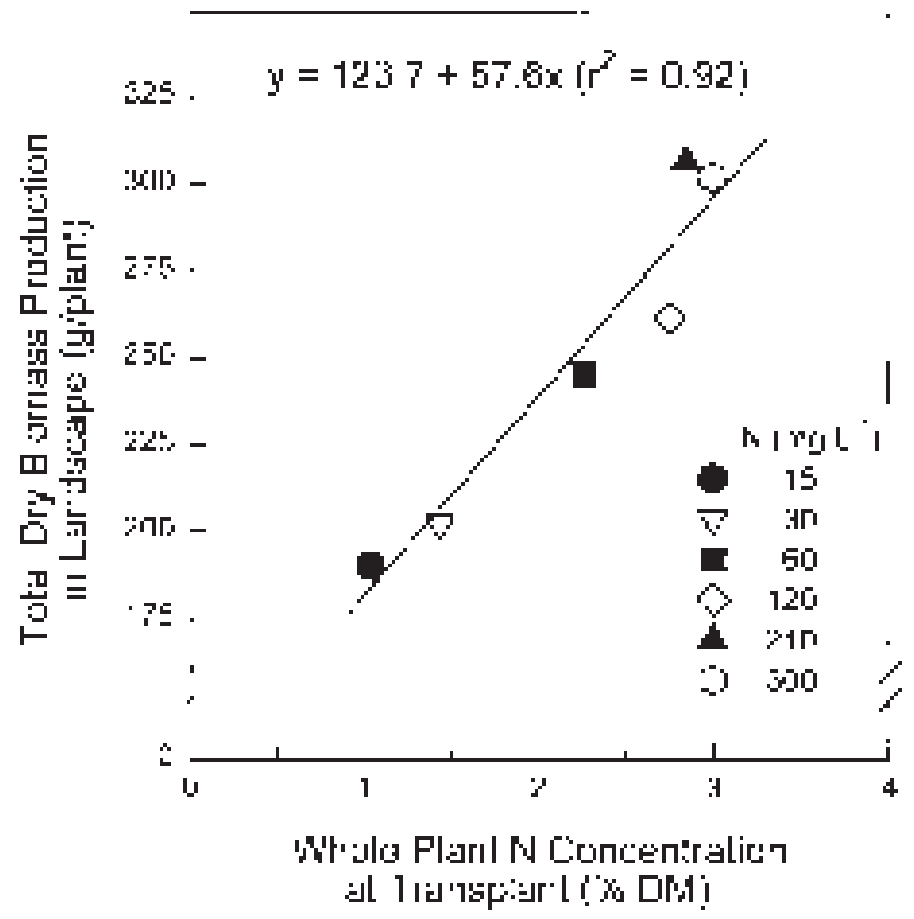

Fig. 2. Dry biomass production of crape myrtle plants 16 weeks after transplanting (WAT) to a landscape soil as affected by plant $\mathrm{N}$ status at transplant. Each data point represents the average for each treatment. 
shown by plants originally grown with high $\mathrm{N}_{\mathrm{A}}$, particularly for root biomass, which showed values similar or higher than those recorded in plants grown at the lowest $\mathrm{N}_{\mathrm{A}}$.

Despite the significant differences observed at transplant among treatments, initial plant size was not a predictor of plant growth in the landscape. These observations, coupled with the fact that leaf tissue $\mathrm{N}$ concentration (Fig. 1G) and color (i.e., greenness or chlorophyll index, Fig. 1H) for all treatments equalized 16 WAT, point to a significant involvement of initial plant $\mathrm{N}$ status and changes or adjustments in the whole plant $\mathrm{C}$ to $\mathrm{N}$ ratio. Work by Ingestad (1979) and Ingestad and Lund (1979) has shown that when birch seedlings grown under optimum conditions were exposed to suboptimum $\mathrm{N}$ supplies they underwent a lag phase, after which growth rate, although lower, was later stabilized. Interestingly, if the rate of $\mathrm{N}$ supply was increased again, the rate of growth by the seedlings was correlated with the rate of $\mathrm{N}$ supply. These responses highlight the ability of plants to adapt their growth, and to adjust their $\mathrm{C}$ to $\mathrm{N}$ ratio, according to $\mathrm{N}$ supply. Similar to the results observed in birch seedling after changes in their $\mathrm{N}$ supply, crape myrtle plants appeared to have a lag phase during the first few weeks after transplant. Thereafter plant growth responses changed significantly and were found to be associated with initial plant $\mathrm{N}$ status (tissue $\mathrm{N}$ concentration).

Plant N status at transplant (expressed as whole plant $\mathrm{N}$ concentration, although leaf $\mathrm{N}$ concentration gave similar results) was linearly and positively correlated with total plant biomass production during the landscape evaluation phase (Fig. 2). Theoretical approaches used to analyze morphological and physiological responses of plants to $\mathrm{N}$ availability have, in fact, predicted that relative growth rate is a nearly linear function of whole plant $\mathrm{N}$ concentration (Hilbert, 1990). These observations in crape myrtle substantiate the view that plant growth potential under limiting $\mathrm{N}$ resources, as in unfertilized landscape sites, would depend on plant tissue $\mathrm{N}$ reserves (Chapin, 1991) until a $\mathrm{C}$ to $\mathrm{N}$ balance is attained (Bloom, 1986; Chapin et al., 1987). A balanced $\mathrm{C}$ to $\mathrm{N}$ ratio is considered essential for productivity and survival of plants under the resource limitations of natural environments (Bloom, 1986). Under this premise plants adjust the expenditure of internal reserves to obtain carbon and $\mathrm{N}$ from the environment in approximately constant proportions; if one resource is scarce, reserves of the other are used to procure the first so that both will become proportionally limiting (Bloom et al., 1985; Chapin et al., 1987).

The dynamics of shoot to root ratio observed in the present study reinforce this ecophysiological premise. Under the managed fertility conditions of the nursery phase, shoot growth was en- hanced over root growth with increases in $\mathrm{N}$ supply, producing high shoot to root ratios (Fig. 1F). This plant response is commonly and extensively reported in both the agricultural and ecological literature (Agren and Ingestad, 1987; Bloom, 1986, Bloom et al., 1985; Chapin, 1988; Chapin et al., 1987; Harris, 1992; Hilbert, 1990; Kozlowski et al., 1991; Marschner, 1995; Wright and Niemiera, 1987). Shoot to root ratios, however, equalized over 16 WAT under the nonmanaged conditions of the landscape phase (Fig. 1F). These observations substantiate the concept that plants, particularly those evolving from resource-rich environments (including most cultivated plants), have the ability to compensate for resource limitations and imbalances by adjusting growth and allocation responses that increase the efficiency with which they use the limiting resources (Bloom, 1986; Bloom et al., 1985; Chapin, 1988; Chapin et al., 1987). Incidentally, the average shoot to root ratio of 4.85 observed in crape myrtle 16 WAT (Table 1) is close to the ratio of 5 to 6 reported for woody plants growing in natural habitats (Harris, 1992; Kozlowski et al., 1991).

The constancy of tissue $\mathrm{N}$ concentration observed across all treatments by 16 WAT (Fig. 1G, Table 2) provides additional support to the apparent inherent tendency of plants towards homeostasis (Chapin et al., 1987; Kozlowski et al., 1991). Further support to this tendency is provided by the equalization of leaf $\mathrm{Ca}$, $\mathrm{S}$ and Fe concentrations 16 WAT (Table 2), nutrients that had also been significantly affected by the $\mathrm{N}$ fertilization regimes during production. This was confirmed by a test of equality of variances (data not shown), which indicated that the wide variance of the mean observed AT for leaf N, S, and Fe concentrations AT was significantly narrowed by 16 WAT.

It is also noteworthy to observe that tissue concentrations of most nutrients 16 WAT were lower than those observed during nursery production (i.e., AT). Incidentally, nutrient values recorded $16 \mathrm{WAT}$ in this study were well within the range of values reported for similar crape myrtle hybrids (Lagerstroemia indica $\times$ L. fauriei) growing in botanical gardens (Mills and Jones, 1996). Furthermore, despite the differences in tissue nutritional status for plants growing in the nursery and those in the landscape, we could not distinguish major differences in plant aesthetics (namely foliage color and appearance). Harris (1992) has reported that foliage color in many street and landscape trees and shrubs is usually acceptable even when their tissue nutrient status would be considered deficient under production conditions. These observations question the validity of using a narrow or specific set of nutrient diagnostic criteria to assess nutrient deficiencies for both plants growing under nursery production conditions and those growing in the landscape.

Table 1. Components of the segmented linear analyses used to evaluate crape myrtle growth responses at 16 weeks after transplant into a landscape with minimum management. Analyses for plants at the end of nursery growing phase (i.e., at transplant) are reported in Cabrera and Devereaux (1998). Data used in analyses are presented in Fig. 1, where correlation coefficients are also indicated for each growth response.

\begin{tabular}{|c|c|c|c|}
\hline Variable & Eq. $[1]^{\mathrm{z}}$ & $\mathrm{X}_{\text {intersection }}{ }^{\mathrm{y}}$ & Eq. [2] \\
\hline Shoot dry mass (g/plant) & $\mathrm{Y}=149.2+1.22 \mathrm{X}$ & 64.8 & $Y=216.6+0.18 X$ \\
\hline Leaf area $\left(\mathrm{m}^{2} /\right.$ plant $)$ & $\mathrm{Y}=0.41+0.0034 \mathrm{X}$ & 188.0 & $\mathrm{Y}=1.19-0.0008 \mathrm{X}$ \\
\hline Canopy diameter $(\mathrm{cm})$ & $Y=59.1+0.74 X$ & 44.6 & $\mathrm{Y}=93.4-0.03 \mathrm{X}$ \\
\hline Plant height $(\mathrm{cm})$ & $\mathrm{Y}=78.7-0.21 \mathrm{X}$ & 117.6 & $Y=50.5+0.03 X$ \\
\hline Root dry mass (g/plant) & $Y=27.4+0.63 X$ & 39.3 & $Y=52.2$ \\
\hline Shoot to root ratio & $Y=4.85$ & --- & --- \\
\hline Leaf nitrogen $(\%)$ & $\mathrm{Y}=2.27$ & --- & --- \\
\hline Leaf greeness index (SPAD units) & $Y=63.4$ & --- & --- \\
\hline
\end{tabular}

${ }^{\mathrm{Z}}$ For equations, Y corresponds to the listed dependent variable, while $\mathrm{X}$ always denotes applied $\mathrm{N}$ concentration (independent variable) during the nursery growing phase.

yThis is the intersection point (i.e., applied $\mathrm{N}$ concentration) of the two lines where the $\mathrm{Y}$ values are equal. Thus, if $\mathrm{X}<\mathrm{X}_{\text {intersection }}$, then use Eq. [1] to predict variable response as a function of the applied $\mathrm{N}$ concentration, and if $\mathrm{X}>\mathrm{X}_{\text {intersection, }}$, then use Eq. [2]. 
Table 2. Average leaf tissue nutrient concentrations (dry mass basis) in crape myrtle plants at transplant (AT) and 16 weeks after transplanting (WAT) to a landscape with minimum management.

\begin{tabular}{|c|c|c|c|}
\hline Element & $\mathrm{AT}^{\mathrm{z}}$ & $16 \mathrm{WAT}$ & $t$ test $^{\mathrm{y}}$ \\
\hline \multicolumn{4}{|c|}{ Macronutrients (\%) } \\
\hline $\mathrm{N}$ & $2.99(1.41-4.06)$ & 2.27 & NS \\
\hline $\mathrm{P}$ & 0.39 & 0.14 & $* * *$ \\
\hline $\mathrm{K}$ & 3.04 & 0.96 & $* * *$ \\
\hline $\mathrm{Ca}$ & $0.91(0.67-1.21)$ & 1.66 & $* * *$ \\
\hline $\mathrm{S}$ & $0.44(0.32-0.71)$ & 0.20 & $* *$ \\
\hline $\mathrm{Mg}$ & 0.48 & 0.36 & $* *$ \\
\hline \multicolumn{4}{|c|}{ Micronutrients $\left(\mathrm{mg} \cdot \mathrm{kg}^{-1}\right)$} \\
\hline $\mathrm{Fe}$ & $243(99-385)$ & 191 & NS \\
\hline Mn & 126 & 87 & $* *$ \\
\hline $\mathrm{Cu}$ & 5 & 9 & $* * *$ \\
\hline B & 42 & 32 & $* *$ \\
\hline $\mathrm{Zn}$ & 105 & 32 & $* * *$ \\
\hline Mo & 1.1 & 0.9 & NS \\
\hline
\end{tabular}

$\overline{{ }^{\mathrm{Z}} \text { Nutrient values shown are the mean of } 24 \text { plants. A range is provided (in parentheses) only for those nutrients significantly affected by applied } \mathrm{N}}$ concentration in the nursery (see Cabrera and Devereaux, 1998 for details). Leaf nutrient values observed 16 WAT were not significantly affected by the former $\mathrm{N}$ nutrition treatments.

${ }^{\mathrm{y}}$ Test (AT vs. 16 WAT) was conducted using only the mean values for each $\mathrm{N}$ treatment (i.e., $\mathrm{n}=6$ ) as tissue analyses were taken from different sets of plants.

Ns,*,**,*** Nonsignificant or significant at $P=0.05,0.01$, or 0.001 , respectively.

Table 3. Flowering response of crape myrtle plants after transplant to a landscape. The plants had been previously grown in the nursery under different $\mathrm{N}$ fertilization regimes.

\begin{tabular}{lccc}
\hline \hline $\mathrm{N}$ treatment $\left(\mathrm{mg} \cdot \mathrm{L}^{-1}\right)$ & $10 \mathrm{WAT}$ & 12 WAT & 3.7 \\
\hline 15 & $1.9^{\mathrm{z}}$ & 3.6 & 3.8 \\
30 & 2.3 & 2.7 & 4.8 \\
60 & 2.8 & 2.6 & 4.5 \\
120 & 1.3 & 1.4 & 4.0 \\
210 & 1.3 & Linear $^{* *}$ & 4.0 \\
300 & 0.8 & Linear & NS \\
Response & $\mathrm{Y}=2.35-0.005(\mathrm{X})$ & $r^{2}=0.92$
\end{tabular}

${ }^{\mathrm{z}} \mathrm{A}$ qualitative scale was used to rate the stage of flower development. Scale: $0=$ no visible flower buds (FBs); $1=$ small FBs; $2=$ swollen FBs; $3=$ FBs showing color plus some fully open flowers; $4=$ full bloom; $5=$ fruit set. Values are means of four plants.

Ns,*,** Nonsignificant or significant at $P=0.05$ or 0.01 , respectively.

Crape myrtle plants flowered during the landscape evaluation phase, with significant differences observed in the timing of flower development and anthesis (Table 3). Plants that had originally been grown with $\mathrm{N}_{\mathrm{A}}$ of 15 to $60 \mathrm{mg} \cdot \mathrm{L}^{-1}$ developed flower buds and reached full anthesis ahead of plants grown at 120 to $300 \mathrm{mg} \cdot \mathrm{L}^{-1}$. It is reported that plant size or relative growth rate determines allocation of plant resources to reproduction, and in many plants a size or biomass threshold must be reached before flowering occurs (Bazzaz, 1997; Bazzaz et al., 1987). The results from the present study suggest that plants grown originally with low to moderate $\mathrm{N}$ supplies attained threshold growth rates sooner, which triggered a reallocation of resources to reproduction. The likely faster attainment of a balanced $\mathrm{C}$ to $\mathrm{N}$ ratio for plants originally fertilized with lower $\mathrm{N}$ supplies, and which had an initial low-intermediate $\mathrm{N}$ status, could be part of this phenomenon. Bazzaz (1997) indicates that often there is a direct linkage between resource availability, the conversion of these resources to biomass, and allocation to reproductive structures.

The results from this study indicate that besides overall plant growth, plant $\mathrm{N}$ status at the end of the nursery phase is a factor that could significantly influence plant performance, particularly growth rates, plant size and flower development, several months after transplant into the landscape. Longer term effects in this regard are, however, unknown and deserve further research attention. On the other hand, it is important to note that, at least under the conditions of the present study, plant survival and establishment per se do not appear to be affected. Not a single plant was lost, and aside from the differences in size and flower timing, all plants were considered aesthetically similar.

\section{Literature Cited}

Agren, G.I. and T. Ingestad. 1987. Root:shoot ratio as a balance between nitrogen productivity and photosynthesis. Plant Cell Environ. 10:579586.

Argo, W.A. and J.A. Biernbaum. 1996. The effect of lime, irrigationwater source, and water soluble fertilizer on root zone $\mathrm{pH}$, electrical conductivity, and macronutrient management of container root media with Impatiens. J. Amer. Soc. Hort. Sci. 121:442-452.

Bazzaz, F.A. 1997. Allocation of resources in plants: State of the science and critical questions, p. 1-37. In: F.A. Bazzaz and J. Grace (eds.). Plant resource allocation. Academic Press, San Diego, Calif.

Bazzaz, F.A., N.R. Chiariello, P.D. Coley, and L.F. Petelka. 1987. Allocating resources to reproduction and defense. BioScience 37:58-67.

Bloom, A.J. 1986. Plant economics. Trends Ecol. Evol. 1:98-100. 
Bloom, A.J., F.S. Chapin III, and H.A. Mooney. 1985. Resource limitation in plants-An economic analogy. Annu. Rev. Ecol. Syst. 16:363-392. Cabrera, R.I. and D. Devereaux. 1998. Effects of nitrogen supply on growth and nutrient status of containerized crape myrtle. J. Env. Hort. 16:98-104.

Carlson, R.M, R.I. Cabrera, J.L. Paul, J. Quick, and R.Y. Evans. 1990. Rapid direct determination of ammonium and nitrate in soil and plant tissue extracts. Commun. Soil Sci. Plant Anal. 21:1519-1529.

Chapin, III, F.S. 1988. Ecological aspects of plant mineral nutrition, p. 161-190. In: P.B. Tinker and A. Lauchli (eds.). Advances in plant nutrition. vol. 3. Praeger, New York.

Chapin, III, F.S. 1991. Integrated responses of plants to stress. BioScience 41:29-36.

Chapin, III, F.S., A.J. Bloom, C.B. Field, and R.H. Waring. 1987. Plant responses to multiple environmental factors. BioScience 37:49-57.

Harris, R.W. 1992. Arboriculture: Integrated management of landscape trees, shrubs, and vines. 2nd ed. Regents/Prentice Hall, Englewood
Cliffs, N.J.

Hilbert, D.W. 1990. Optimization of plant root:shoot ratios and internal nitrogen concentration. Ann. Bot. 66:91-99.

Ingestad, T. 1979. Nitrogen stress in birch seedlings. II. N, K, P, Ca, and Mg nutrition. Physiol. Plant. 45:149-157.

Ingestad, T. and A.B. Lund. 1979. Nitrogen stress in birch seedlings. I. Growth technique and growth. Physiol. Plant. 45:137-148.

Kozlowski, T.T., P.J. Kramer, and S.G. Pallardy. 1991. The physiological ecology of woody plants. Academic Press, San Diego, Calif.

Marschner, H. 1995. Mineral nutrition of higher plants. 2nd ed. Academic Press, San Diego, Calif.

Mills, H.A. and J.B. Jones. 1996. Plant Analysis Handbook II. MicroMacro Publishing. Athens, Ga.

Whitcomb, C. 1986. Plant production in containers. Lacebark Publications, Stillwater, OK.

Wright, R.D. and A.X. Niemiera. 1987. Nutrition of container-grown woody nursery crops. Hort. Rev. 9:75-101. 